\title{
7 Knowledge and Power in the Making of the Soviet Village
}

\author{
Katja Bruisch
}

When the Bolsheviks came to power in October 1917, they were well aware that the control of the countryside was a major condition for the survival of the revolution. Although the late Russian Empire had witnessed an upsurge in industrial development, agriculture remained of central importance in the national economy, while peasants accounted for the vast majority of the population. Yet, after the fall of the Tsarist government earlier that year, rural regions were in a state of turmoil. Peasants had begun to redistribute land, challenging the state's role as the ultimate guarantor of public order. For the Soviet leadership, the countryside was a source of insecurity, rather than a bedrock of stability. During the Civil War period, widespread rural rebellion against mobilization and grain requisitions seriously threatened the Bolshevik's claim to power. The governance of rural regions therefore became a major concern for the new regime. ${ }^{1}$

Against this background, bringing to an end rebellion in the countryside was regarded as a prerequisite for the consolidation of Soviet power. The urge to pacify the peasantry merged with the aspiration to reconfigure social and economic order along the lines of Marxist ideology. Although no concrete ideas existed as to how an ideal socialist village would look and how it would be achieved, there was a consensus within the Soviet leadership about the need to ultimately replace peasant farms with large-scale collective ones, and to integrate the rural regions into the state's hierarchies of administration and control. In the 1920s, the Soviet state established itself as the leading force in the governance of rural areas, supplanting non-governmental organizations that had been active in that field before the revolution. ${ }^{2}$

The central position by the Soviet state in the countryside mirrored an international trend toward increasing state intervention in rural regions. In response to demographic growth and industrialization, growing attention had been paid to agriculture and the rural population in many parts of Europe as well as in the United States from the late nineteenth century. Heightened activity of state officials and experts aimed to turn agriculture into the backbone of the national economy, 
to satisfy agrarian lobby groups and to preserve the rural peripheries as spaces of national culture and identity. ${ }^{3}$

This trend accelerated during the early twentieth century. Driven by the need to feed the troops, state intervention in the countryside increased in warring countries during World War I. Imperial breakdown and the rise of peasant parties turned the so-called "agrarian question" into a sharp political issue in interwar east-central and southeastern Europe. ${ }^{5}$ At the same time, the vision of autarky informed rural politics and research in many European countries, and in Fascist states in particular. ${ }^{6}$ In line with these developments, agriculture had become a political concern in Russia long before the 1917 Revolution. In the late imperial period, institutional reform, the expansion of agricultural education and the regulation of markets were combined to make the rural economy more reliable. ${ }^{7}$ In this context, knowledge about agriculture and the peasantry became a governance resource that was demanded by government agencies, local administrative bodies as well as public organizations. The professionalization and scientization of rural affairs continued after 1917 , offering many experts the pathway into the highest echelons of Soviet bureaucracy. ${ }^{8}$

This chapter explores the relationship between knowledge and power in early Soviet approaches to the governance of rural regions. Drawing upon administrative documents as well as the academic writings of agricultural specialists in the ranks of the People's Commissariat for Agriculture (Narodnyi komissariat zemledeliia, or Narkomzem), I will argue that the different roles played by agricultural experts are symptomatic of the changing patterns of Soviet rule in the countryside. During the first decade after the 1917 Revolution, social reformist approaches dominated, rendering the Russian case similar to that of other European countries at the time, where, in the aftermath of World War I, the experience of crisis merged with a modern belief in the human ability to change the social fabric. ${ }^{9}$ The ideas and debates of experts, however, had but scant impact. During the collectivization campaign at the beginning of the 1930s, coercion and violence were applied on a large scale to transform the rural economy, while agricultural specialists faced marginalization and repression. Originally a project of social and technological engineering, designed to combine order and efficiency with socialist values, collectivization violated the principles of sober and conscious economic planning. Driven by the political elite's wish to gain access to agricultural produce, the making of the Soviet village turned into an arbitrary and ruthless battle for rural resources in the context of Soviet industrialization, and a traumatic experience for millions of people.

\section{The Agrarian Question in Late Imperial Russia}

In the final decades of the nineteenth century, the governance of rural regions became a major political and public issue in the Russian Empire. While the place of the peasantry within the Empire had occupied the 
minds of state officials, scientists and public intellectuals since at least the Emancipation reforms of the early 1860s, the search for the appropriate tools to make the rural regions part of an imagined economic, social and political whole intensified toward the end of the century. Alarmed by a severe famine in 1891-2, contemporaries framed their concern about the countryside using the concept of the "agrarian question" (agrarnyi vopros). ${ }^{10}$ In this context, knowledge of and intervention in local affairs by state and public actors seemed to provide a way out of the desperate cycle of economic crisis and social degradation in which the village seemed to be trapped. A. S. Ermolov, minister of agriculture since 1893 and himself a graduate of the Agricultural and Forestry Institute in Saint Petersburg, one of the Empire's first agricultural training and research institutions, turned knowledge into a tool of agrarian policy, and he invited scientists to become advisors in his ministry. ${ }^{11}$ In the early twentieth century, scientific expertise was applied on a regular basis in order to modernize the countryside. Thousands of agricultural specialists found employment in regional branches of the ministry of agriculture, the rapidly expanding cooperative movement and the organs of local self-government (zemstvos) in particular. ${ }^{12}$ The increasing authority of specialists trained in agricultural sciences or neighboring disciplines also impacted and reshaped the educational landscape of the Russian Empire. Agricultural institutes and faculties with a related focus attracted ever more students, while schools with an agricultural profile mushroomed in many regions of the country. ${ }^{13}$

The rise of the "agrarian question" was accompanied by a considerable change in the way the village was theoretically conceptualized. In collecting data for the organs of rural self-government, which sought to establish local tax systems, statisticians noted that peasants appeared to be principally concerned with satisfying the consumption needs of their families. As A. V. Peshekhonov, a leading statistician of the period, put it: "The peasant lives by virtue and for the sake of the family." ${ }^{14}$ Regardless of the heterogeneity of the Russian Empire's rural regions, statisticians and political economists constructed the peasant household as a distinct type of economic enterprise, one not driven by the pursuit of profit. In their theories the village appeared as a world subject to its own laws, unaffected by the advance of capitalism in the industrial regions of the Empire. ${ }^{15}$ The view of the peasant family as the most important social and economic unit in the countryside also became widespread among members of the Tsarist government, whose policies increasingly addressed individual rural households rather than entire village communities. Most prominently, this paradigm shift was articulated when, in 1906, the so-called Stolypin reforms were launched, which aimed at the abolition of communal tenure. In addition to overcoming communal land-use practices in favor of individual 


\section{K. Bruisch}

farming, improved input supply and the expansion of rural cooperatives were expected to help peasant agriculture to flourish. ${ }^{16}$ The "agrarian question" was thus addressed as a matter of legal order, education and technology.

World War I and the February Revolution in 1917 spurred the diffusion of scientific expertise into the state administration. Considering themselves servants of the "people," many agricultural specialists had hitherto refrained from open support for the Tsarist government. In the context of war, however, their professional biographies became increasingly linked with the demands of the government. Although they continued claiming to act as advocates for the masses, many experts began actually "seeing like a state." 17 Apart from the creation of favorable conditions for rural development, specialists became involved in the management of food and even social resources. Their tasks included the allocation of prisoners of war, refugees or reservists in agriculture as well as the classification of the population according to their importance for warfare, so that different rations of food could be assigned to different categories of the population. Economist A. N. Chelintsev and agronomist P. A. Vikhliaev, for example, calculated how, under war conditions, meat supply could be secured without harming animal husbandry. ${ }^{18}$ The fact that such measures involved favoring or disadvantaging clearly defined social groups did not raise any concerns: applying methods of social engineering had become an unquestioned component in the scientists' professional agenda.

After the fall of the Romanovs in early 1917, many experts considered themselves to be on the threshold of a new rural order. Numerous protagonists of the pre-revolutionary rural modernization campaign joined the interim government's advisory boards. Here they started thinking about a comprehensive land reform that would bring the social imbalances between landowners and peasants to an end and introduce modern farming practices into peasant agriculture. ${ }^{19}$ Economist A. V. Chaianov was enthusiastic: "The agrarian question has left the world of abstract ideas and principles and entered the realm of practical economic-organizational work." ${ }^{20}$ However, while experts made complex calculations about the distribution of land among rural producers, villages were shaken by unrest and violence. Without waiting for a legal solution to the agrarian question, peasants single-handedly seized the land. Thus, when the Bolsheviks took power, the countryside was in a state of chaos and economic decline. War and revolution had shattered all aspirations to bring about a rural order with the help of knowledge and reliable institutions. ${ }^{21}$

\section{Rural Policies after the Bolshevik Takeover}

The 1917 October coup changed the ideology and the institutional setting of rural policies. In need of support from the population's peasant 
majority, the Bolsheviks initiated a fundamental shift in rural property relations. The "Decree on Land" issued immediately after their seizure of power foresaw the expropriation of gentry landholdings and clerical land without compensation, thus legitimizing the spontaneous and arbitrary redistribution of landed property that had taken place in the months after the fall of the Tsarist government. The new leaders also redefined the relationship between government and experts. In the initial years of Soviet power, the organs of local self-government, the outcome of Alexander II's Great Reforms in the mid-nineteenth century, were abolished, while cooperative organizations, an important area of professional activity for many experts, were gradually nationalized. As these changes deprived agricultural specialists of most employment opportunities outside of state institutions, many entered the ranks of the Soviet state apparatus, and particularly the newly founded People's Commissariat for Agriculture (Narkomzem). The benefit of this arrangement was mutual: while the Soviet leadership satisfied their demand for highly qualified professionals, the latter appreciated privileges like exemption from military service and preferential access to food rations, which they were granted as members of the state bureaucracy. ${ }^{22}$ The incorporation of experts into state service was symptomatic of the new approach to the governance of rural regions after the Bolshevik takeover. While in the previous decades public associations, local self-government bodies and the state administration had acted side-by-side, the state now established a monopoly in this area.

Although they set up bureaucratic structures to enforce Soviet power in the village, the Bolsheviks did not pursue a coherent strategy of rural transformation. Given the ongoing battle for power during the Civil War and economic decline in the countryside, rural policies were initially guided by the will for political survival rather than grand, visionary projects. While in 1918 some Bolshevik theoreticians thought they were already close to establishing a socialist economy, coercive requisitioning of agricultural products and the virtual elimination of rural-urban trade shaped reality in the village much more than did the few (and mostly unsuccessful) attempts to introduce collective or state-run farms. ${ }^{23}$ During the first years of Soviet power, Narkomzem, formally conceived as the leading authority in rural affairs, did not have much impact on affairs in the countryside. Instead, the Supreme Council of the National Economy (VSNKh), the highest organ in Soviet economic administration, and the People's Commissariat for Food Supplies (Narkomprod), dictated the direction of agricultural policy. In order to secure supplies for the cities and for the Red Army at the front, independent trading of agricultural goods was prohibited and the peasantry was forced to deliver their produce to Narkomprod's food brigades. As a consequence, the rural population was deprived of any incentive to continue or enhance production beyond personal needs. ${ }^{24}$ Instead of erecting a new rural order, the Bolsheviks perpetuated chaos and crisis in the countryside. 


\section{K. Bruisch}

The adoption of the New Economic Policy (NEP) by the 10th Party Congress in March 1921 initiated a change in this situation. Responding to peasant uprisings and dramatic agricultural decline, the party announced the alliance between workers and peasants (see Figure 7.1) and moved to revitalize the rural economy by lowering pressure on rural producers. In order to increase output, compulsory grain requisitions were replaced by a regular tax and rural-urban trade was legalized to a certain degree, allowing peasants to sell a portion of their produce. With the advance of NEP, the Soviet state even permitted peasants the use of hired labor and, albeit on a limited scale, the lease of land. The political turn, which did not prevent a tragic famine that claimed millions of victims in 1921 and 1922, allowed for the stepwise recovery of agriculture from the devastating effects of war and revolution. Focusing on the improvement of the economic environment for peasant producers, the new course seemed to be a return to the pre-revolutionary model of rural governance, in which the state had undertaken primarily indirect measures in order to spur agricultural production. Yet although many principles of NEP were not in line with aspirations to overcome markets and individual farming, its proponents never abandoned the revolutionary vision of refashioning society and the economy. Rural cooperatives, which began to prosper again in the 1920s, were expected to support the replacement of manual labor with machines. According to the designers of NEP, the advantages of mechanization would sooner or later motivate the peasants to give up

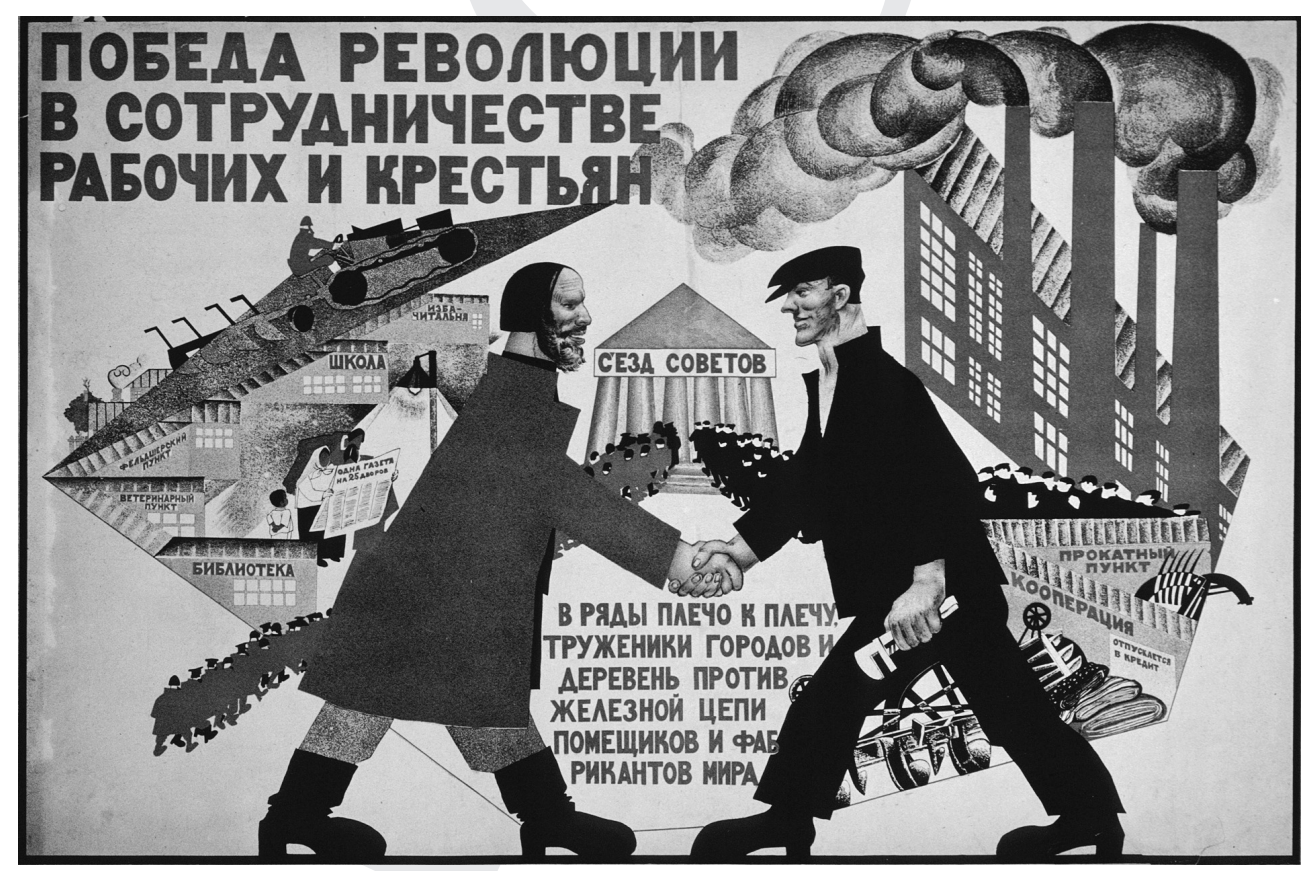

Figure 7.1 "The victory of the revolution is in the alliance of workers and peasants" (early 1920s). Source: Hoover Institution Archives, Poster collection, RU/SU 1384. 
family production and join collective agricultural farms. NEP was thus thought to be a transitional stage in the transformation of the village along socialist lines. ${ }^{25}$

The strengthening of market-economy elements after 1921 went along with the institutionalization of economic planning within the Soviet bureaucracy. In February of that year, the State Commission for the Electrification of Russia (GOELRO) was transformed into the State Planning Committee (Gosplan). Competing views even about the basic principles of planning notwithstanding, Gosplan was put in charge of developing a general plan for the entire economy. ${ }^{26}$ Mentality and political considerations alike were central for the expansion of planning institutions in the context of NEP. On the one hand, it corresponded to a long tradition of anti-capitalist stereotypes within the Russian elite and concrete fears of wild and uncontrolled markets, which had intensified during World War I. ${ }^{27}$ On the other hand, the creation of a central planning agency helped V. I. Lenin reconcile NEP's opponents within the party, as it emphasized that by no means could the new course be interpreted as a renunciation of the Bolsheviks' initial vision of a centrally controlled economy. ${ }^{28}$

The simultaneous occurrence of political and institutional change after the turn to NEP created unseen professional opportunities for nonBolshevik agricultural experts, whose statistical and economic knowledge about the countryside was regarded as fundamental to organizing an efficient rural economy. Leading representatives of the pre-revolutionary zemstvo and cooperative movements occupied key positions within the Soviet planning organs. Gosplan's agricultural section was headed by P. I. Popov, a former zemstvo statistician. Simultaneous to the foundation of a central planning authority, the People's Commissariat for Agriculture set up its own planning commission (Zemplan), which became a major intellectual center in the area of rural governance. ${ }^{29}$ From May 1922, the commission was run by Narkomzem's Deputy Commissar I. A. Teodorovich, a patron of non-party specialists, who appointed N. D. Kondrat'ev as head of Zemplan's scientific staff. ${ }^{30}$

Agricultural planning turned into a domain of the country's leading economists. Kondrat'ev, one of the founders of modern business cycle theory, invented the idea of the "long waves" of economic development. In the 1920s, while heading Narkomzem's planning department, he was also the director of the Conjuncture Institute in Moscow, an internationally highly regarded research institute in the area of macroeconomics and economic crisis. ${ }^{31} \mathrm{~A}$. V. Chaianov contributed to the work of Zemplan as well. In the Soviet Union and abroad, Chaianov became famous for his micro-economic model of the peasant household, which postulated that peasants searched for an equilibrium between the consumption needs and labor force of household members. In the 1960s, Western scholars of development who studied peasant farming embraced Chaianov's writings as a key to understanding Third World economies. ${ }^{32}$ Apart from 


\section{K. Bruisch}

Kondrat'ev and Chaianov, a number of other experts joined Zemplan in the course of the 1920s. ${ }^{33}$ Many of them had either collaborated in the pre-war period or met in 1917 as members of one of the Provisional Government's advisory boards. Thus, the Bolshevik takeover notwithstanding, a strong element of staff continuity prevailed in the state's attempts to modernize the countryside.

\section{Creating Order in the Countryside}

The institutionalization of planning within Soviet bureaucracy reflected the belief that man had the power to shape the social and economic fabric through conscious application of scientific knowledge. Despite divergent ideological orientations, this belief was shared by state officials, party functionaries and experts alike. Upholding a positivist understanding of science and a modernist mindset, they aspired to turn Soviet Russia into an efficiently governed, economically prosperous society. ${ }^{34}$ This did not necessarily imply, however, that the culture of the village had to be completely remodeled. Instead, leading experts claimed that the peasant order was not an obstacle to rural development, provided that knowledge and technological innovation were successfully implemented in the countryside. Most explicitly, this idea was articulated in Chaianov's novel The Journey of My Brother Alexei to the Land of Peasant Utopia, which combined Russian agrarian thought with modernist optimism regarding the capacity of humankind to arrange economy and society along lines of rationality and reason. Chaianov's utopia sketched a rural modernity featuring peasant agriculture, cooperatives and applied sciences, in which highly productive farming methods were embedded in rather traditional forms of social life centered in the peasant household. ${ }^{35}$

The combination of modernist aspirations and a strong preference for peasant farming also informed the work of agricultural experts in the ranks of the People's Commissariat for Agriculture. While Bolshevik hardliners had already developed ideas for the rapid replacement of peasant agriculture by the large-scale collective farm (kolkhoz) during the Civil War, the turn to NEP in 1921 strengthened voices in favor of gradual rural modernization through increased state intervention. Convinced that agricultural policy under NEP was meant to support peasant family farming, leading staff members regarded plans as tools primarily to create order in a countryside that had sunk into chaos and destruction. In 1922, Zemplan started working on a perspective plan for the country's agricultural development. The experts did not interpret this challenge as a request to radically transform the rural order, but rather established guidelines for coordinated agricultural policy according to the basic principles of NEP. Thus, when the commission instructed its branches to compile regional plans, the latter were 
asked to think of policy measures that would "indirectly" (kosvennym putem) stimulate the economic activity of peasant farmers. ${ }^{36}$ Similarly, Narkomzem's Plan for Agricultural and Forestry Development rejected compulsory measures to meet centrally defined production goals. Instead, the text stated that Narkomzem's policy aimed at supporting the rural population's "self-activity" (samodeiatel'nost'), a key concept among promoters of agricultural cooperatives in pre-revolutionary times, by taking their economic interests into account. ${ }^{37}$ According to this approach, peasants would remain independent producers even under conditions of intensified state regulation.

Projecting the village's economic development required detailed knowledge of the current state of the rural economy. Since NEP aimed at fostering individual peasant production and cooperatives, Narkomzem specialists, who in most cases did not have any affiliation with the Bolshevik Party, saw their involvement in agricultural planning as an opportunity to continue their pre-revolutionary agenda for rural development within the structures of the Soviet state. Everyday routine seemed to confirm this impression. As many of them had done before the revolution, Zemplan specialists gathered statistical data on peasant households, calculated the country's prospects for an expansion of agricultural exports and pondered ways to provide rural dwellers with agricultural advice and control of the means of production. ${ }^{38}$ In 1925, during a meeting of the Commissariat's executive board, Kondrat'ev called Zemplan a "scientific operational organ," 39 implying that its main task was to generate scientific knowledge to introduce objective criteria into economic policy. It is striking that Kondrat'ev and his colleagues did not equate agricultural planning with the aim of fundamental change in the rural economy. For them, it embodied rather the vision of "scientific policies," 40 which, once successfully implemented, would turn the village into an arena of modernity.

The commitment to peasant farming among Narkomzem's scientific staff implied a general reservation against state-controlled structures of supply and distribution for agricultural products. As protagonists of the cooperative movement, the experts had criticized the Bolsheviks' first attempts to restrict trade between cities and the countryside during the Civil War. ${ }^{41}$ After the turn to NEP, they could now present their general endorsement of regulated markets and individual farming as approval of the official course and thus emphasize their loyalty to the Soviet government. Narkomzem's General Plan for the Development of Agriculture foresaw a replacement of spontaneous processes in the countryside by planned action (planomernost'). However, for the authors of the plan this did not mean eliminating peasant agriculture and markets. On the contrary: the basic parameters of farming would remain untouched. Rather, the Soviet state would create incentives so that working their fields would 
again become worthwhile for peasant producers, who had been deprived of any economic motivation since their produce had been forcibly requisitioned in the name of the state. Not "reconstruction" (rekonstruktsiia), the main signifier of the state's claim to reshape the rural order during the years of the collectivization, but "recovery" (vosstanovlenie) and "evolution" (evoliutsiia) were therefore the central concepts in the document. ${ }^{42}$

The strong support of Narkomzem experts for combining peasant farming, independent cooperatives and state planning had significant implications for how they defined the relationship between plans and the future. The introduction to Narkomzem's Perspective Plan for the Development of Agriculture and Forestry from 1924 stated that, in fact, the re-establishment of market principles since the beginning of NEP had only created the necessary conditions for a "rational plan," since any economic calculation relied on market prices as a common unit of comparison. ${ }^{43}$ In accordance with the idea that market and plan were in fact two sides of the same coin, experts argued that while outlining the general trend of economic development, plans were not a tool to predestine the future. As unpredictable incidents like price fluctuations or changing weather conditions could never be precluded, concrete prospects for the economy would remain insecure. Expressing the future in quantitative terms therefore appeared to be a mere illusion. Referring to the attempts of Gosplan's leading authority, S. G. Strumilin, a key figure in the development of the First Five Year Plan, to calculate the concrete perspectives of the national economy over the course of five years, Kondrat'ev spoke about a general "hypnosis of figures and arithmetic." ${ }^{44}$ His colleague N. P. Makarov, for whom the "primacy of numeric expression" constituted a major problem in Soviet planning, defined a perspective plan as a "system of economic policy and measures directed at the desired reorganization of the economy." ${ }^{45}$ Narkomzem experts saw planning as an instrument to regulate the economy in its most basic terms. Yet, while hoping to reduce the unpredictability of agriculture, they did not believe that the rural economy could ever be fully controlled. Any project to transform the countryside would therefore have to take into account that the future remained open.

\section{Peasant Politics as a Source of Conflict}

Agricultural planning was a battlefield of conflicting views, as the determination of prices, inputs and outputs affected not only the development of the sector itself, but also the relationship between agriculture and industry, villages and cities, and the rural and urban populations. Designing plans for agriculture was therefore inseparably linked with questions about the future outlook of the country as a whole. Conflicts arose, as in the eyes of many party members, NEP seemed to hamper industrial development, which the Soviet elite had embraced from the 
very beginning as a major strategy to turn Soviet Russia into a socialist state. ${ }^{46}$ From 1924 onwards, secret police reports led to fear that, as a result of the government's conciliatory approach to the peasantry, richer "kulak" peasants were gaining in strength. NEP itself thus appeared as a threat to Soviet rule. ${ }^{47}$

These conflicts shaped the work of Soviet planning institutions. Ideological friction was intense within Gosplan, whose leading functionaries prioritized industrial over agricultural growth, while P. I. Popov, head of Gosplan's agricultural section, was committed to a more balanced development of the agricultural and industrial sectors. ${ }^{48}$ When, in 1925, Narkomzem's Perspective Plan for Agriculture and Forestry Development was presented to Gosplan's executive board, economist L. N. Kritsman called Narkomzem's recommendation for a simultaneous development of industry and agriculture a "populist myth" that ignored the urgent need for accelerated industrialization. ${ }^{49}$ After heated debate, the plan was approved "as a first approximation," but the Gosplan board demanded considerable revisions, which concerned questions that would surface at the heart of Soviet agrarian debate soon thereafter. A new version of the plan should more explicitly consider the accelerating social stratification in the countryside during the NEP period, and propose concrete ideas to foster the industrialization and mechanization of agriculture. ${ }^{50}$ The plan was thus to become a tool for promoting industrial farming, taking into account socialist projections of social order.

Scholarship, ideology and political debate could scarcely be separated in the early Soviet period. Tensions between different groups of experts intensified toward the end of the 1920s when, due to problems with grain acquisition through state organs, peasants were accused of hoarding their grain and criticism of NEP proliferated. In this context, Narkomzem specialists were increasingly blamed for undermining official doctrine by championing the interests of a rural population that was hostile to the Soviet regime. In an academic debate about the social structure of the village, they were attacked by the so-called Agrarian Marxists, a group of scholars led by Gosplan economist Kritsman, which had a strong impact on the scholarly debate about the countryside. Critical of NEP, Agrarian Marxists argued that stratification among the peasantry, ignored by many Narkomzem experts, had accelerated after the partial reintroduction of market relations. ${ }^{51}$ This finding was crucial, and not only for the theoretical analysis of rural society, which up to then had focused on the peasant household, while sociological perspectives on the village had remained less developed. It also contained a political dimension, as it supported the view that NEP was incompatible with the socialist vision of a classless society. Turning the distinction between poor, middle and rich (kulak) peasants, which had already been applied in Soviet policies, into a sophisticated analytical model for understanding 


\section{K. Bruisch}

rural society, Agrarian Marxists provided a theoretical foundation for mounting calls to end NEP. ${ }^{52}$

In light of the state's repeated failure to pursue grain for urban consumers, voices critical of individual farming gained influence in Soviet politics in the second half of the 1920s. In newspaper articles and political debates, peasants were accused of sabotaging the government's efforts to supply the population with what it needed. At the same time, regulations came into force that discriminated against successful agricultural producers and transformed the pejorative label of the kulak into a category of taxation and electoral law. ${ }^{53}$ The 15 th Party Congress in December 1927 signaled the decline of NEP. Its resolution underlined the supremacy of industry over agriculture and announced the stepwise "socialist reconstruction" of the countryside through state-controlled cooperatives and the electrification of farming. Although the text conceded that individual peasant households would still continue to exist, large-scale industrialized agriculture on collective farms was now turned from an ideological credo into a concrete political goal achievable in the foreseeable future. ${ }^{54}$

In this context, Narkomzem experts lost their influence on agricultural politics and the institutional resources previously at their disposal. In 1927, economist Kondrat'ev was accused by V. M. Molotov, a close ally of Stalin's, of promoting an ideology in favor of the kulaks. At the same time, numerous articles blamed Kondrat'ev and other Narkomzem specialists for their skepticism about the government's turn toward accelerated industrialization and a quick rural transformation. ${ }^{55}$ Far-reaching staff changes in Narkomzem indicated that a new wind was stirring in rural policy. In early 1928, A. P. Smirnov, I. A. Teodorovich and A. I. Sviderskii were dismissed from their posts at the top of the Commissariat. The supporters of NEP and patrons of non-party experts were replaced by second-rank functionaries, who could not be suspected of developing a rural governance strategy in opposition to the official course. ${ }^{56}$ In the following months, experts on all levels of the ministry were forced to quit their jobs. Zemplan lost a considerable number of its scientific staff, including Kondrat'ev and Chaianov. ${ }^{57}$ At the same time, scholarship on the peasantry was effectively silenced. In 1928, Kondrat'ev had to vacate his position as director of the world-famous Conjuncture Institute, which was closed down soon after, while Chaianov's Research Institute for Agricultural Economics and Statistics was transmuted into the Institute for the Organization of Large-Scale Farms. ${ }^{58}$ Simultaneously, faculties for collective and state farms were established at the Agricultural Timiriazev Academy in Moscow, securing the new approach to the village a solid place in the curriculum of agricultural studies. ${ }^{59}$

Voices in favor of peasant farming disappeared not only because of the rearrangement of political and academic institutions. Toward the end of the 1920s, the idea that technical progress and economies of scale could 
revolutionize agriculture found support likewise among experts who had previously espoused peasant-based modernization. In a utopian text from 1928, economist Chaianov outlined the implications of technological progress for the future of agriculture. Weather regulation, the extensive use of machinery as well as the development of synthetic methods would help overcome traditional limitations caused by decreasing soil fertility and meteorological constraints, rendering feasible a "factory-like" production of foodstuffs and textile materials. ${ }^{60}$ Following a research stay in the United States, Chaianov's former student G. A. Studenskii praised the advancement of agricultural technology and the enlargement of production units as indicators of successful modernization. ${ }^{61}$ Regardless of whether texts like these were a rhetorical bow in the direction of the new course or the result of increasing optimism about the prospects of large-scale farming, however, they could not shield their authors from harassment by Soviet security organs. In a wave of repression unleashed against "bourgeois specialists" at the end of the 1920s, leading agricultural experts were accused of plotting against the regime and sent to prison. A considerable number of them lost their lives during the Stalinist purges in 1937 and 1938, while others were doomed to an onerous existence at the margins of Soviet society. ${ }^{62}$

\section{The Making of the Soviet Village}

While the Soviet government had experimented with the transformation of the rural economy by setting up collective and state farms during the 1920s, the actual assault on peasant agriculture commenced only after Stalin's ultimate triumph over the supporters of NEP within the party leadership and the adoption of the First Five-Year Plan in 1929. Collectivization was aimed at the modernization of farming practices and rural life and at securing grain procurement, thus combining highmodernist visions of order and efficiency with the government's bid for hegemony and domination in the countryside. Enlarged farms, supplied with modern machinery and run in accordance with modern management approaches, were to overcome the cyclic development of family farming and, at the same time, guarantee that enough grain would be at the state's disposal to feed the expanding non-rural population and to export abroad. Along with the widespread suspicion of individual economic activity among the party's rank and file, rumors about the strengthening of anti-Soviet forces in the countryside served to legitimize the campaign. ${ }^{63}$

The implementation of collectivization was at odds with the aspiration to solve the agrarian question by means of reason and systematic planning. From 1928, when Stalin ordered "extraordinary measures" to secure grain deliveries in Siberia, violence and coercion were an integral part of "socialist transformation" in the countryside. From 1929, 


\section{K. Bruisch}

peasants were increasingly forced to join collective farms (kolkhozes), so that by June 1933 more than 60 percent of Soviet rural households had been collectivized. Compulsory methods included immense financial burdens imposed on individual farmers, discrimination against them during the allocation of land and the open threat of repression. While at times peasants had economic incentives to enter a kolkhoz, the driving motivation for most was the fear of being labeled a kulak, which usually meant expropriation, resettlement and even more serious forms of punishment, including arrest and execution. In 1930 and 1931, during the peak of the campaign, more than 1.8 million kulak peasants fell victim to expropriation and expulsion from their home villages. Most of them were deported to so-called "special settlements" in Siberia and Central Asia. ${ }^{64}$ At the same time, collectivization sparked resistance among the rural population, which regarded it as illegitimate interference by outsiders in village affairs. Excessive slaughter of animals and the destruction of equipment by peasants who were unwilling to surrender livestock and other property to the collective farms became so widespread that authorities saw the need to issue posters against such practices (see Figure 7.2). ${ }^{65}$

The immediate results of the collectivization campaign were devastating. In contrast to the initially promised boost in production, agriculture plummeted into deep decline. Productivity on socialized farms did not meet expectations, and harvests were poor in the period from 1931 to 1933. Additionally, livestock was reduced between 1929 and 1933 by more than half, entailing serious consequences for the supply of dairy and meat products as well as for agriculture itself, as the massive loss of draft animal power could not be compensated by tractors and other machinery. ${ }^{66}$ In the end, collectivization enhanced the state's control over human and economic resources in the countryside, while agricultural output and rural consumption dropped. Moreover, the hasty establishment of the new agrarian order, coupled with compulsory grain deliveries to the state, impacted negatively on agriculture, so that rural regions became even more vulnerable to extreme weather conditions and harvest failure than they had been before. In 1932-3, millions starved to death during a huge famine that plagued the Volga regions, the Ukraine and Kazakhstan in particular. ${ }^{67}$

In the 1930s, little in the Soviet countryside was reminiscent of the high-modernist vision of effective large-scale agriculture. In central, northwestern and northern European Russia in particular, collective farms were rather small, often coinciding with the geographical borders of rural settlements, and their amalgamation went forward slowly. ${ }^{68}$ Regardless of poverty, hunger and economic crisis in the countryside, Soviet media, erecting a veritable "Potemkin village," ${ }^{69}$ celebrated collectivization as a key triumph of socialism. News about the achievements of Soviet rural 


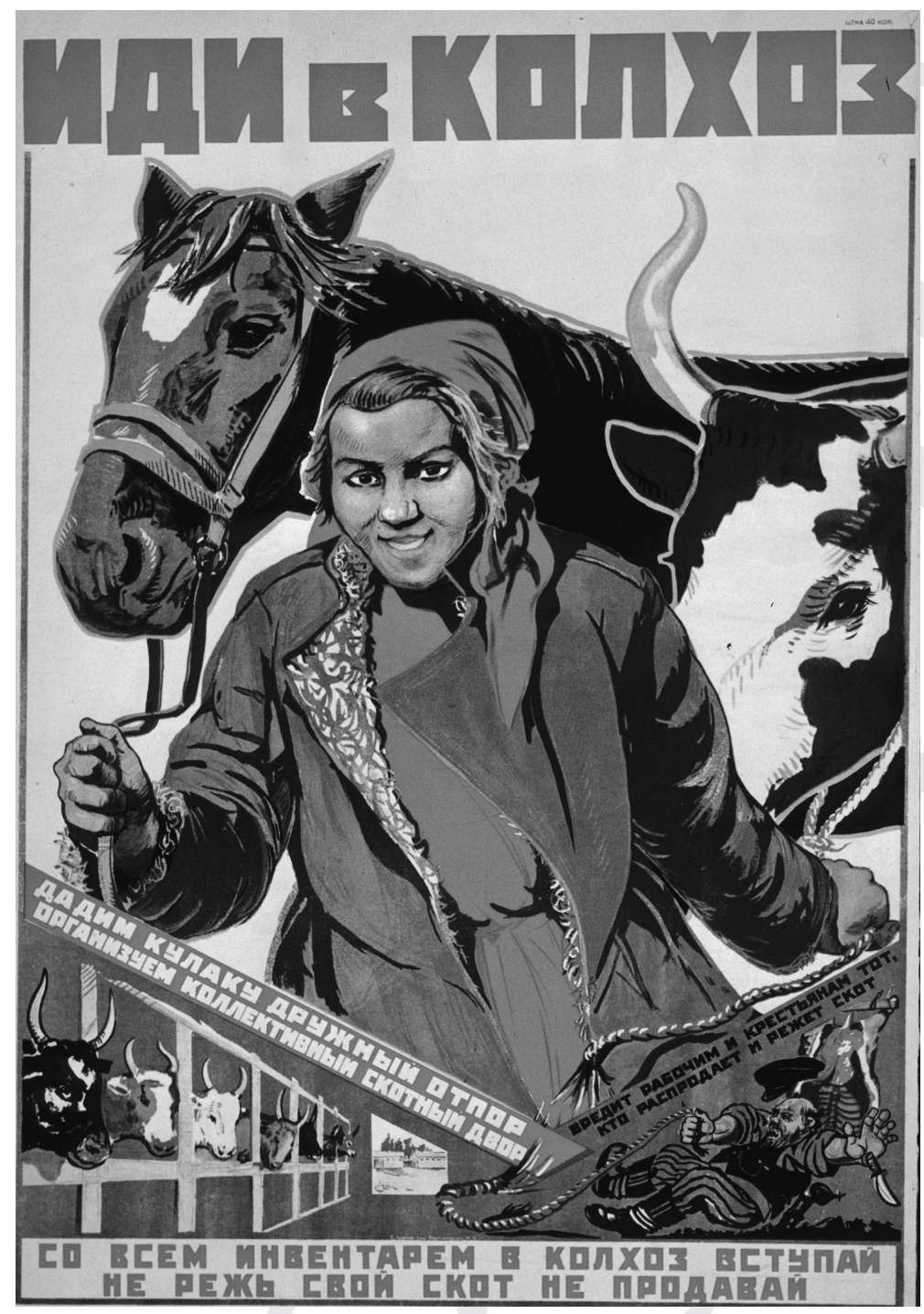

Figure 7.2 "Join the collective farm: Enter the kolkhoz with all your livestock. Don't slaughter your cattle, don't sell it!” (1930s). Source: Hoover Institution Archives, Poster collection, RU/SU 1856.

transformation spread across the globe, feeding the myth that Russia had successfully transitioned from a backward peasant country into a modern state. Convinced that the Soviet experience of large-scale farming could be applicable in capitalist contexts as well, American specialists came to study the purported miracle first-hand. ${ }^{70}$ Yet even model farms that were designed to demonstrate the success of Soviet modernization suffered from a shortage of the most basic tools and machines. ${ }^{71}$ Moreover, while knowledge about the countryside had shaped the agrarian debate since the late nineteenth century and specialists had worked in prominent positions after the 1917 Revolution, scientific experts, regardless of their ideological orientation and social background, were marginalized during 


\section{K. Bruisch}

the making of the Soviet village. ${ }^{72}$ Neither on the farm level nor within the state administration did specialists enjoy the authority to advance agricultural modernization. The primacy of plan fulfillment made the improvement of farming, for example through the invention of sustainable crop rotation schemes or land settlement, virtually impossible. Instead of promoting agricultural change, experts found themselves in the role of scapegoats, held responsible whenever the ambitious targets for grain deliveries to the state could not be met. ${ }^{73}$

The outlook of the collectivized village, as it would exist until the fall of Soviet power, mirrored the circumstances under which it had come into being. Famine and peasant resistance to collectivization ultimately forced the Soviet government to adjust their policies, moving toward a combination of coercion and concession. In 1932, peasants were granted the right to farm a small homestead, to keep cattle and to sell a portion of their private produce. At the same time, the Soviet government tried to tie the rural population tighter to the kolkhozes by refusing to issue them internal passports, which were necessary for legal migration into the cities. The arrangement proved viable, as it allowed the rural population to survive, although on a very meager level, while making it possible for the state to secure the country's food supply. ${ }^{74}$ While initially private farming was seen as a temporary concession, the dual occupation of the rural population on private plots and collective farms became a durable feature of Soviet agriculture. Although the vision of collective industrial agriculture informed agricultural politics until perestroika in the 1980s, household farming played a significant role in food production up until the end of the Soviet period. In 1990, subsidiary plots, which largely relied on manual labor, still accounted for nearly 25 percent of Soviet total agricultural output. ${ }^{75}$

\section{Conclusions}

At the beginning of the twentieth century, the governance of rural regions was regarded as one of the key issues in transforming Russia into a modern nation. Contemporaries were convinced that the integration of the villages into the larger administrative and economic circuits of the Russian Empire would be decisive for the country's prospects to catch up with the more industrialized nations in Europe and the United States, the most important reference systems for imperial elites. ${ }^{76}$ As elsewhere, the growing concern with the rural was labeled the "agrarian question," implying that the countryside's alleged backwardness was slowing down the development of the nation as a whole. After the Bolshevik takeover in 1917, the wish to modernize the rural peripheries combined with the vision to fundamentally change society and economy in accordance with socialist ideals. Given the agricultural decline during World War I and the ensuing revolution and Civil War, the 
intervention of the state in rural affairs appeared as both necessity and opportunity.

In order to achieve their aims, the Soviet government applied means that, during the interwar period, were also common in other European states: regardless of the political system, state policies were guided by the confidence that governments could reshape social and economic relations through knowledge and conscious planning. In the 1920s, the Soviet state relied heavily on the expertise of economists and agronomists, for whom the two decades before the revolution had been a formative period professionally. As peasant farming was put back on the agenda in 1921, the major difference with the pre-revolutionary period resided in the fact that rural affairs were nationalized. Instead of the previous heterogeneity of public and state actors, the state now single-handedly controlled the means and the finances of rural modernization. From an ideological perspective, the NEP years were an ambiguous period. While the Marxist credo of the Soviet rulers implied a clear commitment to scale economies in farming, industrial agriculture was not yet at the center of Soviet policy during the 1920s. Rather, ambitious visions of large-scale collectivized agriculture coexisted with advocacy for peasant-friendly politics, which informed agrarian discourse likewise in western European countries and the United States before industrial farming began to dominate programs of rural modernization, first in industrialized and later in developing countries. ${ }^{77}$

Soviet collectivization has been interpreted as one of many modern attempts to change social life with the help of simplistic schemes that, due to their ignorance of the particularity and diversity of local conditions, were doomed to failure. ${ }^{78}$ The "socialist transformation of the countryside" was meant to combine large-scale industrial farming with the features of a socialist society that had overcome the problems of class and private property. Yet the impact of high-modernist ideas on the making of the Soviet village was negligible. While it is true that the agricultural visions of the planners were hardly compatible with established farming practices and diverse forms of land use, the ultimate gap between plans and outcomes cannot be explained solely by the contradiction between complex rural reality and rigid, standardized plans. The adoption of the First Five-Year Plan, Stalin's rise to power and widespread fears that peasants could withhold the grain needed for the cities' workers, triggered the turn toward the "socialist reconstruction" of agriculture. The enforcement of collectivization, however, was anything but a planned process, contradicting even official statements about the persistence of peasant farming in the foreseeable future. ${ }^{79}$ Symptomatically, instead of experts, thousands of workers, recruited for the promotion of the Soviet cause in the village, alongside the political police, were the state's most important allies during the collectivization campaign, making excessive use of coercion and violence. In the years of the campaign, the measures to foster technical progress and economic efficiency were clearly 


\section{K. Bruisch}

outweighed in their impact on productivity by the massive destruction of input and machinery. The assault on peasant agriculture was thus characterized by the combination of ideology, situative factors and agency, embedded in a political culture of paranoia and violence. Regardless of the undeniable involvement of the Soviet Union in the transnational modernity discourse of the interwar period, collectivization exemplified an argument recently made by Lynn Viola: even though the Soviet Union was a modernizing state, it was not a modern one. ${ }^{80}$

The aspiration to create a homogeneous space of socialist modernity, which dominated Soviet agrarian discourse in the interwar period, paralleled visions of rural transformation common in other authoritarian states of the time. In Italy, Romania and Turkey, for example, the countryside was similarly imagined as a laboratory of modernity brought about by state intervention and the application of scientific and planning knowledge. ${ }^{81}$ While in interwar Romania, Turkey and Germany, the public image of village life was sanitized, no such positive image existed in the Soviet Union. Based on the experience of the Civil War period, the peasantry was depicted not only as backward, but also as a potential source of political unrest. For the Soviet leadership, modernization and control were thus inseparably linked. At the same time, the preferential treatment of the urban population was an ideological imperative in the Soviet Union, legitimizing the discrimination against and repression of the rural population for the greater cause of socialist transformation. In contrast to the Third Reich, where policies oriented to urban consumers were masked by the public acclamation of the peasantry as the bulwark of the nation, ${ }^{82}$ urban modernity was the manifest leitmotiv of Soviet discourse.

Yet, although collectivization was driven by the focus on the urban consumer rather than the rural producer, the Soviet leadership was forced to make concessions to the peasants, allowing for individual farming on private plots. In the long run, however, this compromise proved satisfactory neither for the state nor for the rural population. While productivity in Soviet agriculture remained comparatively low, the persistent gap between rural and urban living standards drove millions to leave the villages in the decades after World War II. ${ }^{83}$ Voting with their feet, the rural population terminated the agreement on which the Soviet model of rural governance had been based since the establishment of the kolkhoz system at the beginning of the 1930s.

\section{Notes}

1 Landis, Bandits and Partisans; Retish, Russia's Peasants in Revolution and Civil War.

2 Heinzen, Inventing a Soviet Countryside; Wehner, Bauernpolitik im proletarischen Staat. 
3 Federico, Feeding the World, 187-220. For an overview on the intellectual reactions to rural-urban migration and industrialization, see Mai, "Agrarische Transition und industrielle Krise." The intellectual turn toward the countryside could also contain a progressivist element: Rodgers, Atlantic Crossings, 318-366. On the increasing role of the state in agriculture, see Patel, "The Paradox of Planning."

4 Ermacora, "Rural Society."

5 van Meurs, "Demokratie oder Sozialismus?"; Gollwitzer, Europäische Bauernparteien im 20. Jahrhundert.

6 On the German case, see Oberkrome, Ordnung und Autarkie. On autarky and fascism, see Saraiva and Wise, "Autarky / Autarchy," and the other contributions in this issue.

7 Yaney, The Urge to Mobilize.

8 Bruisch, Als das Dorf noch Zukunft war; Gerasimov, Modernism and Public Reform.

9 Doering-Manteuffel, "Ordnung jenseits der politischen Systeme."

10 Kotsonis, Making Peasants Backward. On changing representations of peasants in elite discourse, see Frierson, Peasant Icons.

11 Elina, Ot tsarkikh sadov do sovetskikh polei, Vol. 2, 57-62.

12 Gerasimov, Modernism and Public Reform, 88-98; Matsuzato, "The Fate of Agronomists in Russia." On zemstvos, see Emmons and Vucinich, The Zemstvo in Russia.

13 Agronomicheskaia pomoshch'v Rossii, ed. V. V. Morachevskii (Petrograd: Departament Zemledeliia, 1914), 259-314.

14 A. V. Peshekhonov, "Iz teorii i praktiki krest'ianskogo khoziaistva," Russkoe bogatstvo 9 (1902): 179.

15 Johnson, "Liberal Professionals and Professional Liberals"; Darrow, "From Commune to Household."

16 For a brief overview of the aims and the outcomes of the reform, see Macey, "Reflections on Peasant Adaptation."

17 Gerasimov, Modernism and Public Reform, 153.

18 Glavnyi Komitet Vserossiiskogo Zemskogo Soiuza, Ėkonomicheskie Soveshchaniia pri Glavnom Komitete Vserossiiskogo Zemskogo Soiuza, 2830 aprelia i 21-22 iulia 1916 goda (Moscow, 1916), 199-206.

19 Bruisch, Als das Dorf noch Zukunft war, 107-120.

20 A. V. Chaianov, Chto takoe agrarnyi vopros (Moscow: Universal'naia biblioteka, 1917), 9.

21 On the 1917 developments in the countryside, see Lih, Bread and Authority in Russia, chapters 3 and 4.

22 Bruisch, Als das Dorf noch Zukunft war, 142-151, 179-190; Wehner, Bauernpolitik, 94-110; Heinzen, Inventing a Soviet Countryside, 65-69.

23 Hildermeier, Geschichte der Sowjetunion, 146-147.

24 Heinzen, Inventing a Soviet Countryside, 34-36.

25 Merl, Der Agrarmarkt; Ball, "Building a New State and Society."

26 Zaleski, Planning for Economic Growth in the Soviet Union, 35-44.

27 Holquist, Making War, Forging Revolution, 18-22.

28 Hildermeier, Geschichte der Sowjetunion, 233-248.

29 Wehner, Bauernpolitik, 118.

30 Heinzen, Inventing a Soviet Countryside, 69. 


\section{K. Bruisch}

31 Barnett, "A Long Wave Goodbye.”

32 On the origins and rediscovery of Chaianov's theory, see Bruisch, Als das Dorf noch Zukunft war, 60-66, 312-317.

33 Among these experts were the economists N. P. Makarov, A. N. Chelintsev and A. A. Rybnikov, the agronomists A. G. Doiarenko and A. V. Teitel as well as the statistician and public intellectual N. P. Oganovskii. Russian State Archive of the Economy (RGAE), f. 478, op. 2, d. 286, 11. 1-5.

34 Taking the example of the Central Statistical Administration (TsSU), this has been demonstrated by Alain Blum and Martine Mespoulet, Biurokraticheskaia anarkbiia. The authors argue that, notwithstanding the technocratic approach of the government, the cooperation between Bolsheviks and non-party experts was based on a "great misunderstanding," as Bolshevik doctrine always implied a fundamental break with the previous political, economic and social order.

35 Chaianov published this text in 1920 under a pseudonym. An English translation appeared more than fifty years later: Ivan Kremnev (1920), "The Journey of my Brother Alexei to the Land of Peasant Utopia," Journal of Peasant Studies 4, no. 1 (1976): 63-108. See Raskov, "Socialist Agrarian Utopia in the 1920s," 123-146 for a recent interpretation.

36 RGAË f. 478, op. 2, d. 201, 1. 97-98.

37 Narodnyi komissariat zemledeliia, Osnovy, 78.

38 Bruisch, Als das Dorf noch Zukunft war, 206-217.

39 RGAĖ, f. 478, op. 1, d. 1560, 11. 5-6.

40 Raphael, "Die Verwissenschaftlichung des Sozialen,” 169.

41 Bruisch, Als das Dorf noch Zukunft war, 134-142.

42 RGAĖ f. 478, op. 2, d. 156, 11. 1-2; Bruisch, Als das Dorf noch Zukunft war, 215-224.

43 Narodnyi komissariat zemledeliia, Osnovy perspektivnogo plana razvitiia sel'skogo i lesnogo khoziaistva (Moscow: Novaia derevnia, 1924), 5.

44 N. D. Kondrat'ev, "Plan i predvidenie ( $k$ voprosu o metodakh sostavleniia perspektivnykh planov razvitiia narodnogo khoziaistva i sel'skogo khoziaistva v chastnosti)," Puti sel'skogo khoziaistva, no. 2 (1927): 22.

45 N. P. Makarov, "Nekotorye ocherednye voprosy metodologii sostavleniia perspektivnykh planov po sel'skomu khoziaistvu," Puti sel'skogo khoziaistva, no. 2 (1927): 42.

46 Hildermeier, Sowjetunion, 248-253.

47 Hudson, "The Kulakization of the Peasantry."

48 Wehner, Bauernpolitik, 117-122.

49 "Osnovy perspektivnogo plana razvitiia sel'skogo i lesnogo khoziaistva: Plenarnoe zasedanie Prezidiuma Gosplana SSSR 25 iiulia 1925," Puti sel'skogo khoziaistva, no. 1 (1926): 203.

50 "Perspektivnyi plan razvitiia sel'skogo i lesnogo khoziaistva: Plenarnoe zasedanie Prezidiuma Gosplana SSSR 1 sentiabria 1925 g.," Puti sel'skogo khoziaistva, no. 4 (1926): 159-167.

51 Gross Solomon, The Soviet Agrarian Debate, 115-125.

52 Thus, Kritsman and two of his colleagues worked closely with party politician V. M. Molotov, who in late 1927 initiated a change of course in rural policies. Wehner, Bauernpolitik, 354-357; David-Fox, Revolution of the Mind, 214-215; Bruisch, Als das Dorf noch Zukunft war, 240-241. 
53 Wehner, Bauernpolitik, 306-308; Merl, Der Agrarmarkt und die Neue Ökonomische Politik, 427.

54 XV S-ezd Vsesoiuznoi Kommunisticheskoi Partii-(b). Stenograficheskii otchet (Moscow, Leningrad: Gosudarstvennoe izdatel'stvo, 1928): 1304-1317.

55 Wehner, Bauernpolitik, 325-328; Blum and Mespoulet, Biurokraticheskaia anarkhiia, 185-188.

56 Heinzen, Inventing a Soviet Countryside, 195-196; Wehner, Bauernpolitik, 374-382.

57 Bruisch, Als das Dorf noch Zukunft war, 244.

58 RGAE், f. 8390, op. 2, d. 14, 1. 43, 45-46.

59 Gross Solomon, The Soviet Agrarian Debate, 156-157; Mironowa, "Der Sturm auf die Agrarwissenschaften"; Bruisch, Als das Dorf noch Zukunft war, 244-247.

60 A. V. Chaianov, "Vozmozhnoe budushchee sel'skogo khoziaistva," in: Zhizn' i tekhnika budushchego (Moscow: Moskovskii rabochii, 1928), 260-285.

61 G. A. Studensky, "The Agricultural Depression and the Technical Revolution in Farming," Journal of Farm Economics 12, no. 4 (1930): 552-572.

62 Bruisch, Als das Dorf noch Zukunft war, 248-257, 295-302.

63 On the high-modernist vision of the collectivized village, see Scott, Seeing Like a State, 193-222; Tauger, "Stalin, Soviet Agriculture and Collectivisation."

64 Numbers taken from Davies and Wheatcroft, The Years of Hunger, 46, 488.

65 Fitzpatrick, Stalin's Peasants; Viola, Peasant Rebels under Stalin.

66 Davies and Wheatcroft, The Years of Hunger. See also Leonard, Agrarian Reform in Russia, 68-73.

67 See the classic study by Conquest, Harvest of Sorrow. On the impact of environmental factors, see Tauger, "Natural Disaster and Human Actions." The famine remains a topic of debate among historians: Ellman, "Stalin and the Soviet Famine."

68 On farm amalgamations in the 1930s, see Berg, Reform in the Time of Stalin, 20-54.

69 Fitzpatrick, Stalin's Peasants, 262-285.

70 Fitzgerald, "Blinded by Technology."

71 Smith, Works in Progress, 21-62.

72 This affected not only "bourgeois" specialists at Narkomzem. Even the Agrarian Marxists, who from an ideological standpoint had seemed to be so close to the ruling elite, were muzzled at the beginning of the 1930s. See Gross Solomon, The Soviet Agrarian Debate, 168-170.

73 Merl, "Why did the Attempt under Stalin."

74 Merl, "Bilanz der Unterwerfung," 121-124, 140-143; Leonard, Agrarian Reform, 206.

75 Hedlund, Private Agriculture.

76 On the Westernizing discourse of Russian elites, see Kingston-Mann, In Search of the True West.

77 Harwood, Europe's Green Revolution.

78 This is the major argument in Scott, Seeing Like a State.

79 Merl, "Why did the Attempt under Stalin."

80 On the distinction between the modern and the modernizing state and the role of violence and arbitrariness in the Soviet Union, see Viola, "The Question of the Perpetrator," 20-21. 


\section{K. Bruisch}

81 Mușat, "Lessons for Modern Living."

82 Patel, "Paradox of Planning," 244-255.

83 Pallot, "Rural Depopulation."

\section{References}

Ball, Alan. "Building a New State and Society: NEP, 1921-1928." In The Cambridge History of Russia. Volume III: The Twentieth Century, 168-191. Edited by Ronald Grigor Suny. Cambridge: Cambridge University Press, 2006.

Barnett, Vincent. "A Long Wave Goodbye: Kondrat'ev and the Conjuncture Institute, 1920-28.” Europe-Asia Studies 47, no. 3 (1995): 413-441.

Berg, Auri C. Reform in the Time of Stalin: Nikita Khrushchev and the Fate of the Russian Peasantry. Ph.D. diss., University of Toronto, 2012.

Blum, Alain and Martine Mespoulet. Biurokraticheskaia anarkhiia: Statistika i vlast' pri Staline. Moscow: ROSSPE்N, 2006.

Bruisch, Katja. Als das Dorf noch Zukunft war: Agrarismus und Expertise zwischen Zarenreich und Sowjetunion. Cologne: Böhlau, 2014.

Conquest, Robert. Harvest of Sorrow: Soviet Collectivisation and the TerrorFamine. New York: Oxford University Press, 1986.

Darrow, David W. "From Commune to Household: Statistics and the Social Construction of Chaianov's Theory of Peasant Economy." Comparative Studies in Society and History 43, no. 4 (2001): 788-818.

David-Fox, Michael. Revolution of the Mind: Higher Learning Among the Bolsheviks, 1918-1929. Ithaca: Cornell University Press, 1997.

Davies, R. W. and Stephan G. Wheatcroft. The Years of Hunger: Soviet Agriculture, 1931-1933. Second Edition. New York: Palgrave Macmillan, 2009.

Doering-Manteuffel, Anselm. "Ordnung jenseits der politischen Systeme: Planung im 20. Jahrhundert." Geschichte und Gesellschaft 34, no. 4 (2008): 398-406.

Elina, Ol'ga Iu. Ot tsarkikh sadov do sovetskikh polei: Istoriia sel'skokhoziaistvennykh opytnykh uchrezhdenii XVIII - 20-e gody XX veka. 2 Volumes. Moscow: Institut istorii, estestvoznaniia i tekhniki RAN, 2008.

Ellman, Michael. "Stalin and the Soviet Famine of 1932-33 Revisited." EuropeAsia Studies 59, no. 4 (2007): 663-693.

Emmons, Terence and Wayne S. Vucinich, eds. The Zemstvo in Russia: An Experiment in Local Self-Government. Cambridge: Cambridge University Press, 1982.

Ermacora, Matteo. "Rural Society." In 1914-1918-online: International Encyclopedia of the First World War. Edited by Ute Daniel, Peter Gatrell, Oliver Janz, Heather Jones, Jennifer Keene, Alan Kramer and Bill Nasson, issued by Freie Universität Berlin, Berlin 2015. Doi: http://dx.doi.org/10.15463/ ie1418.10530.

Federico, Giovanni. Feeding the World: An Economic History of Agriculture, 1800-2000. Princeton: Princeton University Press, 2005.

Fitzgerald, Deborah. "Blinded by Technology: American Agriculture in the Soviet Union.” Agricultural History 70, no. 3 (1996): 459-486.

Fitzpatrick, Sheila. Stalin's Peasants: Resistance and Survival in the Russian Village after Collectivization. New York: Oxford University Press, 1994.

Frierson, Cathy A. Peasant Icons: Representations of Rural People in Late Nineteenth-Century Russia. New York: Oxford University Press 1993. 
Gerasimov, Ilya V. Modernism and Public Reform in Late Imperial Russia: Rural Professionals and Self-Organization 1905-1930. Houndmills: Palgrave Macmillan, 2009.

Gollwitzer, Heinz, ed. Europäische Bauernparteien im 20. Jahrhundert. Stuttgart: Gustav Fischer Verlag, 1977.

Gross Solomon, Susan. The Soviet Agrarian Debate: A Controversy in Social Science, 1923-1929. Boulder: Westview Press, 1977.

Harwood, Jonathan. Europe's Green Revolution and Others Since: The Rise and Fall of Peasant-Friendly Plant Breeding. London: Routledge, 2011.

Hedlund, Stefan. Private Agriculture in the Soviet Union.London: Routledge, 1989.

Heinzen, James W. Inventing a Soviet Countryside: State Power and the Transformation of Rural Russia, 1917-1929. Pittsburgh: University of Pittsburgh Press, 2004.

Hildermeier, Manfred. Geschichte der Sowjetunion 1917-1991: Entstehung und Niedergang des ersten sozialistischen Staates. Munich: Verlag C. H. Beck, 1998.

Holquist, Peter. Making War, Forging Revolution: Russia's Continuum of Crisis, 1914-1921. Cambridge, MA: Harvard University Press, 2002.

Hudson, Hugh. "The Kulakization of the Peasantry: The OGPU and the End of Faith in Peasant Reconciliation, 1924-1927." Jahrbücher für Geschichte Osteuropas 60, no. 1 (2012): 34-57.

Johnson, Robert E. "Liberal Professionals and Professional Liberals: The Zemstvo Statisticians and Their Work." In The Zemstvo in Russia: An Experiment in Local Self-Government, 343-363. Edited by Terence Emmons and Wayne S. Vucinich. Cambridge: Cambridge University Press, 1982.

Kingston-Mann, Esther. In Search of the True West: Culture, Economics, and Problems of Russian Development. Princeton: Princeton University Press, 1999.

Kopsidis, Michael, Katja Bruisch and Daniel W Bromley. "Where is the Backward Russian Peasant? Evidence against the Superiority of Private Farming, 18831913." The Journal of Peasant Studies 42, no. 2 (2015): 425-447.

Kotsonis, Yanni. Making Peasants Backward: Agricultural Cooperatives and the Agrarian Question in Russia, 1861-1914. New York: St. Martin's Press, 1999.

Landis, Erik C. Bandits and Partisans: The Antonov Movement in the Russian Civil War. Pittsburgh: University of Pittsburgh Press, 2008.

Leonard, Carol S. Agrarian Reform in Russia: The Road from Serfdom. Cambridge MA: Cambridge University Press, 2011.

Lih, Lars T. Bread and Authority in Russia 1914-1921. Berkeley: University of California Press, 1990.

Macey, David A. J. "Reflections on Peasant Adaptation in Rural Russia at the Beginning of the Twentieth Century: The Stolypin Agrarian Reforms." In Rural Adaptation in Russia, 38-64. Edited by Stephen K. Wegren. London: Routledge, 2005.

Mai, Gunther. "Agrarische Transition und industrielle Krise: Anti-Modernismus in Europa in der ersten Hälfte des 20. Jahrhunderts." Journal of Modern European History 4, no. 1 (2006): 5-38.

Matsuzato, Kimitaka. "The Fate of Agronomists in Russia: Their Quantitative Dynamics from 1911-1916." Russian Review 55, no. 2 (1996): 172-200.

Merl, Stephan. Der Agrarmarkt und die Neue Ökonomische Politik: Die Anfänge staatlicher Lenkung der Landwirtschaft in der Sowjetunion 1925-1928. Munich: Oldenbourg, 1981. 


\section{K. Bruisch}

Merl, Stephan. "Bilanz der Unterwerfung - die soziale und ökonomische Reorganisation des Dorfes." In Stalinismus vor dem Zweiten Weltkrieg: Neue Wege der Forschung, 119-144. Edited by Manfred Hildermier. Munich: Oldenbourg, 1998.

Merl, Stephan. "Why did the Attempt under Stalin to Increase Agricultural Productivity Prove to be Such a Fundamental Failure?" Cahiers du monde russe 57 (2016). Accessed July 3, 2017. http://monderusse.revues.org/8343.

van Meurs, Wim. "Demokratie oder Sozialismus? Bauernparteien in Südosteuropa um die Jahrhundertwende als Träger der Demokratisierung. Eine Skizze." Archiv für Sozialgeschichte 53 (2013): 93-112.

Mironowa, Tatjana P. "Der Sturm auf die Agrarwissenschaften.” In Im Dschungel der Macht: Intellektuelle Professionen unter Stalin und Hitler, 106-120. Edited by Dietrich Beyrau. Göttingen: Vandenhoeck \& Ruprecht, 2000.

Muşat, Raluca. "Lessons for Modern Living: Planned Rural Communities in Interwar Romania, Turkey and Italy." Journal of Modern European History 13, no. 4 (2015): 536-550.

Oberkrome, Willi. Ordnung und Autarkie: Die Geschichte der deutschen Landbauforschung, Agrarökonomie und ländlichen Sozialwissenschaft im Spiegel von Forschungsdienst und DFG, 1920-1970. Stuttgart: Steiner, 2009.

Pallot, Judith. "Rural Depopulation and the Restoration of the Russian Village under Gorbachev." Soviet Studies 42, no. 4 (1990): 655-674.

Patel, Kiran Klaus. "The Paradox of Planning: German Agricultural Policy in a European Perspective, 1920s to 1970s." Past and Present 212, no. 1 (2011): 239-270.

Raphael, Lutz. "Die Verwissenschaftlichung des Sozialen als methodische und konzeptionelle Herausforderung für eine Sozialgeschichte des 20. Jahrhunderts." Geschichte und Gesellschaft 22, no. 2 (1996): 165-193.

Raskov, Danila. "Socialist Agrarian Utopia in the 1920s: Chayanov." Economia 4, no. 2 (2014): 123-146.

Retish, Aaron B. Russia's Peasants in Revolution and Civil War: Citizenship, Identity, and the Creation of the Soviet State, 1914-1922. Cambridge: Cambridge University Press, 2008.

Rodgers, Daniel T. Atlantic Crossings: Social Politics in a Progressive Age. Cambridge, MA: Belknap Press of Harvard University Press, 1998.

Saraiva, Tiago and M. Norton Wise. "Autarky / Autarchy: Genetics, Food Production, and the Building of Fascism." Historical Studies in the National Sciences 40, no. 4 (2010): 419-428.

Scott, James C. Seeing Like a State: How Certain Schemes to Improve the Human Condition Have Failed. New Haven: Yale University Press, 1998.

Smith, Jenny Leigh. Works in Progress: Plans and Realities on Soviet Farms 1930-1963. New Haven: Yale University Press 2014.

Tauger, Marc B. "Natural Disaster and Human Actions in the Soviet Famine of 1931-1933." The Carl Beck Papers in Russian \& East European Studies, no. 1506 (2001).

Tauger, Marc B. "Stalin, Soviet Agriculture and Collectivisation." In Food and Conflict in Europe in the Age of the Two World Wars, 109-142. Edited by Frank Trentmann and Flemming Just. Basingstoke: Palgrave Macmillan, 2006.

Viola, Lynne. Peasant Rebels under Stalin: Collectivization and the Culture of Peasant Resistance. New York: Oxford University Press, 1996. 
Viola, Lynne. "The Question of the Perpetrator in Soviet History.” Slavic Review 72, no. 1 (2013): 1-23.

Wehner, Markus. Bauernpolitik im proletarischen Staat: Die Bauernfrage als zentrales Problem der sowjetische Innenpolitik 1921-1928. Cologne: Böhlau, 1998.

Yaney, George L. The Urge to Mobilize: Agrarian Reform in Russia, 1861-1930. Urbana: University of Illinois Press, 1982.

Zaleski, Eugène. Planning for Economic Growth in the Soviet Union, 19181932. Chapel Hill: University of North Carolina Press, 1971. 